\title{
DEVELOPMENT OF LOCAL GOVERNANCE AND DECENTRALIZATION TO EMPOWER CITIZENS IN PAKISTAN: A HISTORICAL ANALYSIS
}

\author{
Zain Rafique, Yeni Rosilawati, Shahid Habib ${ }^{\mathbf{1}}$ \\ National University of Modern Languages, Universitas Muhammadiyah Yogyakarta
}

\begin{abstract}
:
Contemporary development discourse confers a protuberant role to decentralization and local governance. To comply with this developmental demand, the Government of Pakistan introduced local governance and decentralization measures to use local governance system as a platform for localizing development and engaging local citizens. This article explores the historical level of the local governance system in Pakistan and the manifold problems that contributed to the absence of an adequate and capable local government system. Empowerment, accountability and transparency mechanisms in local governance systems are not functioning properly and hence the performance and results of the local governance system are very unsatisfactory.
\end{abstract}

Keywords: Local Government, Pakistan, decentralization, citizen participation

Título en Castellano: Desarrollo de la gobernanza local y la descentralización para empoderar a los ciudadanos en Pakistán: un análisis histórico

\section{Resumen:}

El discurso del desarrollo contemporáneo confiere un papel protuberante a la descentralización y la gobernanza local. Para cumplir con esta demanda de desarrollo, el Gobierno de Pakistán introdujo medidas de gobernanza local y descentralización para utilizar el sistema de gobernanza local como una plataforma para localizar el desarrollo e involucrar a los ciudadanos locales. Este artículo explora el nivel histórico del sistema de gobierno local en Pakistán, se revelaron múltiples problemas que contribuyeron a la ausencia de una idoneidad adecuada del sistema de gobierno local Además, los mecanismos de empoderamiento, responsabilidad y transparencia en los sistemas de gobernanza local no funcionan correctamente y, por lo tanto, el rendimiento y la eficacia del sistema de gobernanza local son muy insatisfactorios.

Palabras Clave: Gobierno local, Pakistán, descentralización, participación ciudadana

Copyright $\odot$ UNISCI, 2019.

Las opiniones expresadas en estos artículos son propias de sus autores, y no reflejan necesariamente la opinión de UNISCI. The views expressed in these articles are those of the authors, and do not necessarily reflect the views of UNISCI.

\footnotetext{
${ }^{1}$ Zain Rafique is Assistant Professor at the Department of Governance and Public Policy, National University of Modern Languages, Islabamad. E-mail: <zainrfq@gmail.com>. Yeni Rosilawati, Lecturer at the Communication Department, Universitas Muhammadiyah Yogyakarta. E-mail: <yenirosilawati@gmail.com>. Shahid Habib is Assistant Professor at the Department of Governance and Public Policy, National University of Modern Languages, Islabamad. E-mail: 〈Shabib@numl.edu.pk>.

DOI: http://dx.doi.org/10.31439/UNISCI-92
} 


\section{Introduction}

Local government is an important tier of governance at grass root level, whereas in other countries local government institutions are considered merely an administrative arrangement to perform some of the government tasks at local level ${ }^{2}$. However, local government institutions are the administrative units in a larger governmental frame ${ }^{3}$. In political science and public administration literature, local government is considered as semi-government institutions, selfgoverned by the residents and functioning under federal, central or country government through some directives, regulations and legal bindings ${ }^{4}$. As per the researcher's understanding, their functions, roles, and responsibilities are not similar to state institutions but to redress daily needs of common people, more particularly local government institutions usually perform municipal functions. There are many terms to identify local government institutions, such as, counties, communes, parish, municipal committees, districts, towns, unions and local boards ${ }^{5}$. In Pakistan, we have local Boards, local bodies, district councils, local councils, local government institutions and others ${ }^{6}$.

Lord Ripen, the founder of local government in United India, called it the nursery of democracy $^{7}$. As per Pakistan's perspective, the local councils are the primary institutions to ensure participation of the residents of a particular locality, under their own supervision, to regulate all aspects of their routine daily life. Through participation in elections, and later by engagements in various functions or activities, carrying out by local level government institutions with regard to people's everyday needs, these institutions may serve as model training schools for the citizen to learn the skills of self-rule ${ }^{8}$.

Pakistan is an Islamic and federal republic with three specific tiers of government: local, provincial and central ${ }^{9}$. The Constitution of Pakistan protects the local government under Articles 140-A and 32 which is the $3^{\text {rd }}$ tier of Pakistan government ${ }^{10}$. Under local government acts, the country is divided into Districts, Tehsils (sub-districts) and Union Councils, with each Union Council comprising a number of villages. In addition, each province has its own legislation, ministries and specified government acts for its implementation. Metropolitan corporations and district council are the highest urban and rural tiers respectively in the provinces. Local government in each province consists of two or three tiers. Metropolitan corporations and district councils have substantial responsibilities as they are involved in local economic development, road, healthcare, education and policing with the provincial governments and also with the lower tiers for the services such as environmental protection, libraries, museums as well as water and sanitation. As far as the central and provincial governments are concerned, Pakistan is a federal republic that has a bi-cameral people elected

\footnotetext{
${ }^{2}$ Stoker, Gerry. (1988): The politics of local government, London, Springer.

${ }^{3}$ Rhodes, Raw: "The new governance: governing without government", Political studies, Vol.44, no.4 (1996), pp. 652-667.

${ }^{4}$ Lowndes Vivien, Pratchett Lawrence and Stoker Gerry: "Trends in Public Participation: Part 1-Local Government Perspectives", Public Administration, Vol.79. n¹ (2001), pp. 205-222.

${ }^{5}$ Abers, Rebecca: "From clientelism to cooperation: local government, participatory policy, and civic organizing in Porto Alegre, Brazil”, Vol.26, no 4 (December, 2001), pp. 511-537.

${ }^{6}$ Cheema, Ghulam Shabbir (2007): "Devolution with accountability: learning from good practices", in Decentralizing Governance: Emerging Concepts and Practices, Washington, Brookings Institution Press, pp. 216301.

${ }^{7}$ Tinker, Hugh. (1954): The Foundations of the Local Self-government in India, Pakistan and Burma, London, Athlone Press.

${ }^{8}$ Abraham, Kow Kwegya Amissah (2019): "The role and activities of policy institutes for participatory governance in Ghana." In Public Policy Research in the Global South, Cham, Springer, pp. 151-170.

${ }^{9}$ Musarrat, Razia, and Azhar, Sultan: "Decentralization Reforms in Pakistan During Ayub and Zia Era", Journal of Public Administration and Governance, Vol. 2, no. 1 (2012), pp.123-133.

${ }^{10}$ Munir, Mughal. and Ahmad, Bashir. (1996): Constitution of the Islamic Republic of Pakistan: Being a Commentary on the Constitution of Pakistan, 1973, Lahore, PLD Publishers.
} 
parliament consisting of two houses namely national assembly and senate. ${ }^{11}$ Head of the state is president but functional powers are with the Prime minister. Senate members are selected by provincial assembly of each province. The number of seats are 104. While, out of 342 seats in national assembly, parliamentarians on 272 seats are directly elected from single member constituencies by universal adult suffrage through a single transferable vote while 10 seats are reserved for religious minorities and sixty (60) seats are exclusively reserved for females which are proportionally allocated ${ }^{12}$. Usually, the prime minister comes from the largest party.

Pakistan consists of four provinces. Members of provincial assemblies are directly elected through general elections with the membership of 51 in Baluchistan, 124 in Khyber Pakhtunkhwa, 164 in Sindh and 371 in Punjab. In each provincial assembly, 2-5\% and 20\% seats are reserved for religious minorities and women respectively (Alam and Wajidi 2013).

This article has provided an overview of history of local governance system of local government in Pakistan. In order to understand local government system of Pakistan, it is essential to discuss the local governance reforms implemented in Pakistan so far. This article starts by looking at the concept of local government and general government structure of Pakistan. It then looks at the legal basis of local government in Pakistan and structure of local governments in Pakistan since its inception. Lastly, it analyzes the current local government act and puts forth the researchers' point of view.

\section{Local Government of Pakistan}

\subsection{Legal Basis for Local Governments in Pakistan}

As discussed in the earlier sections, Pakistan's constitution protects the local government under its articles 140-A and Article 32. Article 32 states:

Promotion of local government institutions. The state shall encourage local government institutions composed of elected representatives of the areas concerned and, in such institutions, special representation will be given to peasants, workers and women ${ }^{13}$.

Article 140-A states: Each province shall, by law, establish a local government system and devolve political, administrative and financial responsibility and authority to the elected representatives of the local governments ${ }^{14}$.

These two above stated articles of federal constitution provide the base for local government in Pakistan. In addition, every province has its own local government law. Under these laws, every province conducts the local government elections. Table 1 below gives an overview of the all the legislations by all the provinces and territories.

\footnotetext{
${ }^{11}$ From 1947 to 1973 , the country had had a unicameral system, but under the 1973 Constitution, Pakistan adopted a bicameral federal legislature, called Parliament, composed of the President, the Senate and the National Assembly.

${ }^{12}$ Alam, Munnawar and Wajidi, Muhammad Abuzar: "Pakistan's Devolution of Power Plan 2001: A brief dawn for local democracy?", Commonwealth Journal of Local Governance, Vol. 12, no 1 (2012), pp.20-34.

${ }^{13}$ Munir, Mughal. and Ahmad, Bashir. (1996): Constitution of the Islamic Republic of Pakistan: Being a Commentary on the Constitution of Pakistan, 1973, Lahore, PLD Publishers.

${ }^{14}$ Ibid., p. 78.
} 
Table 1. Main Local Government Legislation by Province/Territory

\begin{tabular}{ll} 
Province/territory & Main local government legislation \\
Baluchistan & Baluchistan Local Government Act 2010 \\
\hline KPK & Khyber Pakhtunkhwa Local Government Act 2013 \\
\hline Punjab & Punjab Local Government Act 2013 \\
\hline Sindh & Sindh Local Government Act 2013 \\
\hline Gilgit-Baltistan & Gilgit-Baltistan Local Government Act 2014 \\
\hline \multirow{3}{*}{ Cantonments } & Cantonment Laws (Amendment) Act 2013 \\
& Cantonment Local Government (Elections) Rules \\
\hline \multirow{2}{*}{ Islamabad CT } & 2015 \\
\hline
\end{tabular}

Source: Authors own elaboration, 2020

Under these legislations, local government elections were held in provinces during different times. The list of recent local government elections along with their turn out is presented in Table 2 below.

Table 2. Pakistan Local Government Elections and Turnout Percentage

\begin{tabular}{lll} 
Province/territory & Last election & Turnout (\%) \\
\hline Balochistan & Dec 2013 & 26.84 \\
\hline Khyber Pakhtunkhwa & May 2015 & 43.52 \\
\hline Punjab & Oct 2015 & 61.11 \\
\hline Sindh & Oct 2015 & 46.26 \\
\hline Islamabad Capital Territory & Sept 2015 & 54.87
\end{tabular}

Source: Own elaboration from data of Khan, Iftikhar (2016), Turnout declined in 2015 LG polls, Dawn News.

\subsection{Structure of Local Government in Pakistan}

When there is no representative local government in any province, administration in each district is headed by a district administrator, usually a bureaucrat. Even when there is an elected local government, still their role has prime importance as they control the local government. The local government system has three tiers, Councils, Tehsils and Districts ${ }^{15}$. Each tier has its own specific service functions and responsibilities. At tehsil level, the focus is on health, community development, education and agriculture. Infrastructure and municipal services are focused at the level of district while community services take place at union level. All these three levels of local government are unified and integrated with the help of a bottom up system comprised of explicit electoral arrangements, planning systems, and specific procedures for monitoring service delivery ${ }^{16}$. Provinces are responsible for holding local government elections and keeping ministerial oversight. At the federal level, the Ministry of Inter Provincial Coordination provides a coordination role. District councils and metropolitan corporations are

\footnotetext{
${ }^{15}$ Khan, Shadi. (2006): Local Government and Participatory Rural Development The Case Study of District Government in North Western Pakistan, DI Khan, Gomal University Press.

${ }^{16}$ Alam, Munnawar and Wajidi, Muhammad Abuzar: "Pakistan's Devolution of Power Plan 2001: A brief dawn for local democracy?", Commonwealth Journal of Local Governance, Vol. 12, no 1 (2012), pp.20-34.
} 
the highest tier of local government in provinces, whilst both urban and rural local government have two or three tiers in all provinces.

\subsection{Distribution of Service Delivery Responsibility}

There can be provincials' difference in Pakistan but usually districts are responsible for intradistrict roads, agriculture, dispensaries, health, sanitation and water, literacy and education. Tehsils are responsible for street services that includes sanitation, sewer, water supply and lighting etc, local streets and road, cultural events, markets, fairs and slaughterhouses etc ${ }^{17}$. Metropolitan corporations are responsible for all the integrated services. Union councils are responsible for grazing areas, cattle pounds, ponds and wells, street services, local streets and libraries. Usually, these council work along with neighborhood villages and councils to coordinate and promote developmental activities. They are also responsible to propose annual plan at tehsil and district level to budgetary allocations ${ }^{18}$.

\section{Methodology and Analysis}

This study aims to provide an overview of history of local governance system of local government in Pakistan for the assessment of development of Local Governance and Decentralization to empower Citizens in Pakistan. The research methodology for this article is based on secondary sources of data. The data was collected through extensive review of literature and systematic documentary analysis. Document analysis is a form of qualitative research in which documents are interpreted by the researcher to give voice and meaning around an assessment topic. In this study, documents and secondary data collection includes the review of Government Acts, government gazettes, documents, NGOs working papers, minutes of meetings, national \& provincial policy papers, budget statements. The researchers have analyzed all these materials. All the available data was analyzed and interpreted. There are many reasons to assess the local government to study empowerment of citizen participation and governance ${ }^{19}$. Most of the citizens of Pakistan are the direct beneficiaries of service delivery by local governments. Moreover, as per the Local Government Act of 2013, Punjab Local Government (Citizen Community Boards) Rules of 2003 and the Punjab Development of Cities Act of 1976, local government bodies are regulated to ensure citizen participation but the actual empowerment of citizens in local government is still unknown. The current article applies the documentary analysis to inspect all the secondary data closely to search for recurrent topics, themes or relationships and marking identical passages.

\subsection{Local Government in Pakistan: Historical Analysis (1947-2016)}

This is not in the scope of the thesis to discuss local government history but it is essential to summarize it in order to understand the current decentralization and local government system of Pakistan. It is evident that in a state, there can be a shadow or parallel group of institutions which hold actual powers. In Pakistan's case, it is true. Pakistan has faced four Martial laws in her short history and each government introduced different brand of citizen participation and Local government ${ }^{20}$. So, for a better understanding, we have to see the local government system in Pakistan separately in the military and civil regimes. Cheema ${ }^{21}$ called these martial regimes

\footnotetext{
${ }^{17}$ Nurmandi, Achmad, and Purnomo, Eko Priyo: "Making the strategic plan work in local government: a case study of strategic plan implementation in Yogyakarta Special Province (YSP)", International Review of Public Administration, Vol. 16, $\mathrm{n}^{\circ} 2$ (2011): pp.143-164

${ }^{18}$ Hasnain, Zahid: "Devolution, Accountability, and Service Delivery in Pakistan", The Pakistan Development Review, Vol. 49, nº 2 (Summer 2010): pp.129-152.

${ }^{19}$ Jabeen, Nasira and Iqbal, Muhammad Zafar: "Gender and local governance in Pakistan: Promoting participation through capacity building", South Asian Studies, Vol.25, no 2 (2010), pp. 255-277.

${ }^{20}$ Gauhar, A. (1996): Ayub Khan: Pakistan's First Military Ruler, USA, Oxford University Press.

${ }^{21}$ Cheema, Ghulam Shabbir (2007): "Devolution with accountability: learning from good practices", in Decentralizing Governance: Emerging Concepts and Practices, Washington, Brookings Institution Press, pp. 216301.
} 
as 'non-representative governments'. The researcher has assessed that in developing countries, citizen participation and decentralization can be externally driven (for instance through donor pressures or adjustment programs) or internally motivated (from governments to gain popularity or legitimize their existence). In Pakistan's case, citizen participation processes and decentralization in local government is usually internally driven. The researchers claims that prime motivation behind citizen participation processes and decentralization reforms during military regimes were for the legitimization or their rule ${ }^{22}$. This actually did not empower the citizens and local government. The researchers argued that military regimes only safeguard their own interests ${ }^{23}$. It was further strengthened this argument by arguing that local government in South Asia is stronger in authoritarian regimes. It was found out that citizen participation platforms and local governance system is usually weak during democratic systems. The next sections provide an overview of the local government reforms in Pakistan until 2001 ${ }^{24}$.

\subsection{Local Government in Pakistan until 2001}

Local government reforms can be divided into five periods from 1947 until 2001. These are explained separately in sub sections.

\subsection{Post-Independence to Ayub Period (1947 - 1958)}

After independence, local government system was run by authorities appointed by federal government. The local government was superseded or controlled by federal or provincial bureaucracy and local election were halted. During this decade, mechanism of citizen participation was obsolete while local governance system was weak. Increased centralization of institutions dominated by armed and civil bureaucracy was going on ${ }^{25}$. During 1956, some of the progress was started to elect local government bearers but this was limited to Punjab and Bengal (afterwards, Bangladesh). Up till 1958, Most of the councils were being managed by the administrators appointed by federal government. In most of the cases, elections were not held after the office terms. But local government system was full of massive mal-practices and limited franchise ${ }^{26}$. There was no roam for citizen participation during this decade.

\subsection{The Ayub Period: (1958 - 1969)}

During this period, the first martial law was imposed by the then Field Marshal Ayub Khan. He introduced major local government reforms with the name, Basic Democracy (BD system). Local councils were installed in rural and urban areas. An electoral collage of 40,000 was selected through elections. All these elected officials were responsible for the section of federal and provincial members ${ }^{27}$. This new local government system was established under Municipal Ordinance of 1960 and BD Ordinance of $1959^{28}$. Direct citizen participation was not given priority but through their local elected councilors, citizens were able to influence in the local government institutions. The researcher is of the view that this system of controlled democracy,

\footnotetext{
${ }^{22}$ Rafique, Zain and Khoo, Suet Leng: "Role of community-based organizations (CBOs) in promoting citizen participation: A survey study of local government institutions of Punjab, Pakistan”, International Journal of Sociology and Social Policy, Vol.38, nº.3/4 (2018), pp. 242-258.

${ }^{23}$ Bhave, Aditya. and Kingston, Christopher: "Military Coups and the consequences of durable De Facto Power: The case of Pakistan", Economics of Governance, Vol. 11, nº 1, (2010), pp. 51-76.

${ }^{24}$ Azmat, Fara, Alam, Quamrul and Coghill, Ken: "Integrated governance: A pre-requisite for sustainable marketoriented development in Bangladesh". International Journal of Public Administration, Vol. 32, no.10 (2009), pp. 829-851.

${ }^{25}$ Jalal, A. (1995): Democracy and Authoritarianism In South Asia: A Comparative and Historical Perspective, London, Cambridge University Press.

${ }^{26}$ Rafique, Zain., Khoo, Suet Leng, \& Idrees, Muhammad Waqas: "Civic engagement among the youth: empirical evidence from Kashmir, Pakistan”, Humanomics, Vol.32, no 3 (2016), pp. 376-388.

${ }^{27}$ Siddiqui, K. (1992): Local government in South Asia: a comparative study, Dhaka, University Press.

${ }^{28}$ Zaidi, Syed Akbar: "Urban Local Government in Pakistan: Expecting Too Much from Too Little?", Economic and Political Weekly, Vol. 31, nº 44 (November 1996), pp. 2948-2953
} 
local government system and limited citizen participation was developed to legitimize the military regime. One of the researcher also opined that all this patronage and governance reforms were military regime technique to secure its legitimacy and public mandate ${ }^{29}$.

\subsection{Period of 1969 - 1979}

During this period, all the bodies of local government system were dissolved. All the powers and authorities were with the local government officials and federal or provincial governments. During this period, East Pakistan was seceded from Pakistan and became Bangladesh while West Pakistan was separated into four provinces. During this period, constitution of Pakistan was set where provincial governments were given the subject of local government. Citizen participation during this period was ineffective.

\subsection{The Zia Period (1979 - 1985)}

During this period, a second wave of local governance reforms was marked. A local government ordinance was given by the then Martial law administrator, General Zia. For the first time in Pakistan, elections were held simultaneously both in urban and rural areas on non-party bases ${ }^{30}$. Direct citizen participation was not the priority of the government but urban and rural areas were unified through local government laws and harmonized representations were given to minorities, women, workers and peasants. People participated through their respective local council and devolution of power actually happened. All the union councils were given significant autonomy. Councils were allowed to propose their taxations proposals and budgets ${ }^{31}$. The researchers's analysis of local government ordinance and Basic Democracy Ordinance shows that though it brought some devolutions of power but citizens were not empowered $^{32}$. Therefore, devolution of power and autonomy of local governance system were solely for the legitimization of military government and did not translate into substantive empowerment of Citizens.

\subsection{Evolution of the Local Government Structure 1985-1999}

The revival of federal and provincial assemblies in 1985 took back the power from local government to provincial and federal governments. The dominance of these revived assemblies by local bodies' politicians helped transplant the culture of local body politics to the provincial and national levels ${ }^{33}$. During this era, citizen participation was totally ignored as these elected officials of provincial and federal assemblies use the budget of development for their own vested interests. During this period, politics of Personalization was at its peak and citizen participation was totally ignored. Moreover, local government was also exacerbated due to the clash between the provincial and federal governments over the authority ${ }^{34}$. Resultantly, the friction between provincial and local government body resulted into a total halt of local

\footnotetext{
${ }^{29}$ Myerson, Roger: "Constitutional structures for a strong democracy: considerations on the government of Pakistan", World Development, Vol. 53, no 2 (January 2004), pp. 46-54

${ }^{30}$ Cheema, Ghulam Shabbir (2007): "Devolution with accountability: learning from good practices", in Decentralizing Governance: Emerging Concepts and Practices, Washington, Brookings Institution Press, pp. 216301.

${ }^{31}$ Jalal, A. (1995): Democracy and Authoritarianism In South Asia: A Comparative and Historical Perspective, London, Cambridge University Press.

${ }^{32}$ Hasnain, Zahid: "Devolution, Accountability, and Service Delivery in Pakistan", The Pakistan Development Review, Vol. 49, nº 2 (Summer 2010), pp.129-152.

${ }^{33}$ Wilder, Andrew. (1999): The Pakistani Voter: Electoral Politics and Voting Behaviour in the Punjab, London, Oxford University Press.

${ }^{34}$ Mansuri, Ghazala. and Rao, Vijayendra: "Community-Based and-Driven Development: A Critical Review". The World Bank Research Observer, Vol.19, nº 1 (2004), pp. 1-39.
} 
government from 1993 to 1998 . Figure 1 below gives an overview of the functions of local government in Pakistan until 2001.

\section{Figure 1. Local Government Structure in Pakistan until 2001}

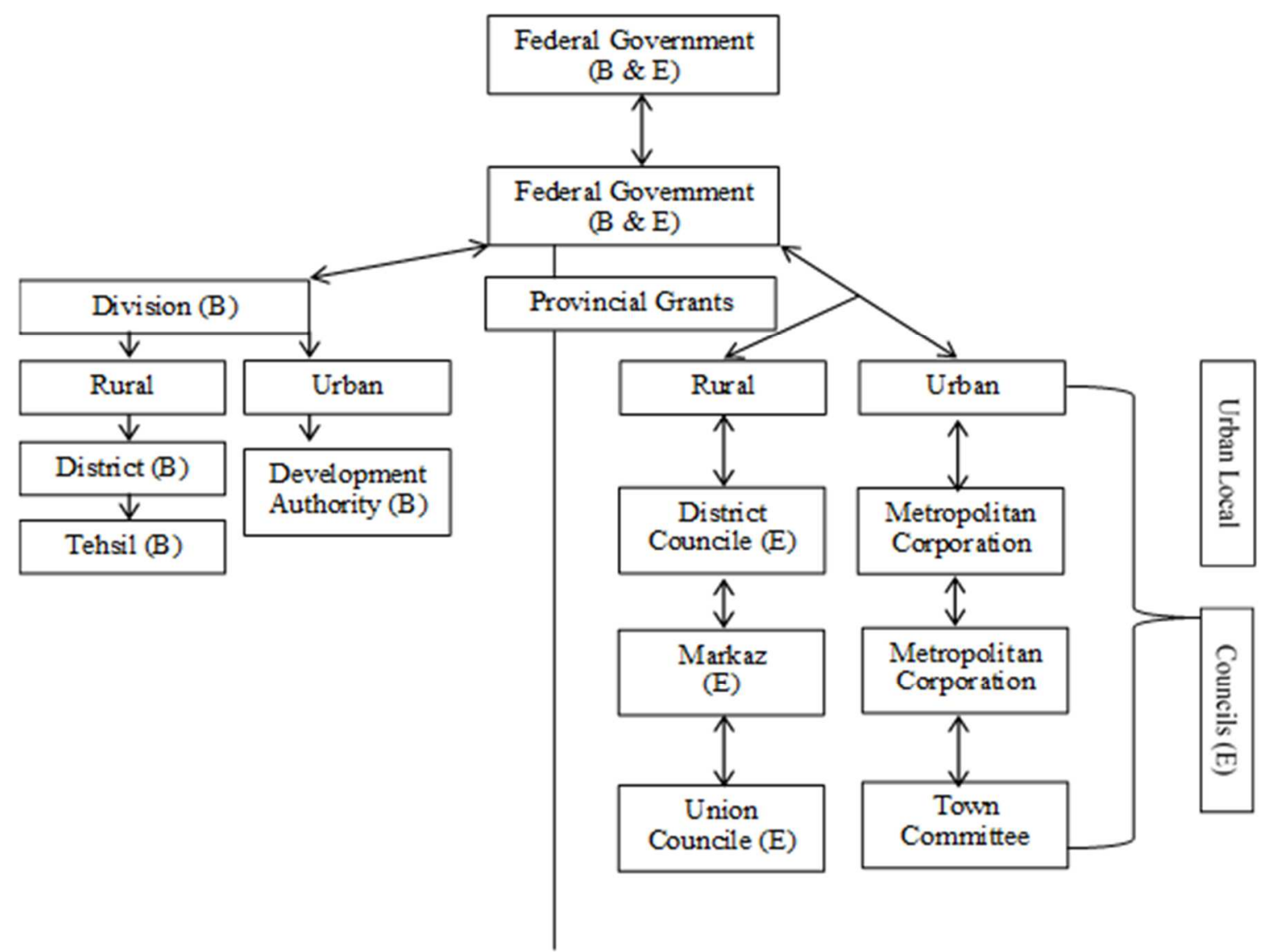

Source: Own elaboration from data of literature reviewed Note. (B) stands for bureaucracy, while (E) stands for elected

\subsection{Devolution of Power Plan (Post 1999)}

Coup of 1999 facilitated the devolution of power to the citizens and at local level. But earlier, participatory reforms and governance reforms were started by international lenders and donors. Most particularly World Bank ${ }^{35,36}$. Based on the World Bank reports of 1998 and 1996, the researchers 37 contended that multilateral pressures for participatory reforms and decentralization policies developed in Pakistan in mid-nineties ${ }^{38}$. Before that, there was no unified effort by World Bank or any other development agencies to promote citizen participation. Thus, the researcher can assume that citizen participation reforms were started in Pakistan on the directions of international development agencies. Moreover, military coup of 1999 can be called as the turning point for local governance reforms in Pakistan. The Devolution of Power Plan of 2001 (hereafter, DOPP) was based on the concept of citizen

\footnotetext{
${ }^{35}$ Sirker, Karen and Cosic, Sladjana. (2007): Empowering the Marginalized: Case Studies of Social Accountability Initiatives in Asia, Washington, D.C., The World Bank.

${ }^{36}$ Mansuri, Ghazala. and Rao, Vijayendra: "Community-Based and-Driven Development: A Critical Review". The World Bank Research Observer, Vol.19, nº 1 (2004), pp. 1-39.

${ }^{37}$ Cheema, Ali, Khwaja, Asim Ijaz and Qadir, Adnan: "Local government reforms in Pakistan: context, content and causes." Decentralization and local governance in developing countries: A comparative perspective, no. 2 (2006), pp. 257-284.

38 Abraham, Kow Kwegya Amissah (2019): "The role and activities of policy institutes for participatory governance in Ghana." In Public Policy Research in the Global South, Cham, Springer, pp. 151-170.
} 
participation and subsidiarity. It helped to transfer the power from provincial and federal governments to lower levels. Direct citizen participation was ensured through CCBs, CACs, Muhallah committees and CBOs. Generally, DOPP was comprised of two elements electoral reforms and decentralization. Moreover, civil services reforms and police reforms were also done. Table 3 below presents an overview of DOPP.

Table 3. The Devolution of Power Plan of 2001

- Voting age reduced from 21 to 18 years to bring youth into mainstream politics.

- Minimum educational qualification prescribed for candidates for Nazims (mayors).

Electoral - Manifesto mandatory for candidates for District and Town/Taluka Nazims (mayors).

- Elections conducted by (central) Election Commission of Pakistan instead of provincial election authorities.

- Local government elections held in phases for better management and coordination.

\begin{tabular}{lll}
\hline Gender & Reserved seats for women increased to 33\% in all tiers of local government. \\
\hline & - & Divisional tier (between districts and provincial government) abolished. \\
& Office of the Deputy Commissioner (a colonial legacy of de-concentrated \\
administration) abolished and replaced by senior District Coordination & Officer (DCO) reporting to Nazim (mayor); interaction of DCO with \\
provincial government through mayor. & Magistracy abolished; in Pakistan's context this was very important, as \\
& provincial governments extended their reach through district officers who \\
also had judicial powers that could be exploited through the district \\
bureaucracy. \\
Mayor made chief executive of the respective local government with wide \\
ranging administrative and financial powers. \\
Elaborate mechanism for internal and external recall of elected \\
representatives prescribed under law; similarly, officials enabled to seek \\
recourse against motivated or illegal orders of Nazims (mayors).
\end{tabular}

Source: Alam, Munnawar and Wajidi, Muhammad Abuzar (2013): Pakistan's Devolution of Power Plan 2001: A brief dawn for local democracy?

Under this system, planning and finance, IT, community development, education, health, agriculture and most particularly revenue were entirely given to district governments, the upper tier, which were provincial subjects earlier. This made the local governments more competent and empowered. The middle tier, taluka/town governments were assigned the functions such as waste disposal, roads, sanitation and water. The third tier, union council was envisaged as providing oversight and monitoring of small developmental projects and service delivery. 
Union councils were not dependent on provincial government and received most of its funds from district government or from local taxes. This direct local taxation increased the direct citizen participation. Moreover, the role of CSOs was also effective as it allowed direct citizen participation in the local government. This new system also demolished the rural urban divide that was previously practiced in the local government. Figure 2 below gives an over-view of the functioning of local governance system until 2009.

Figure 2. Functioning of Local Government of Pakistan until 2009

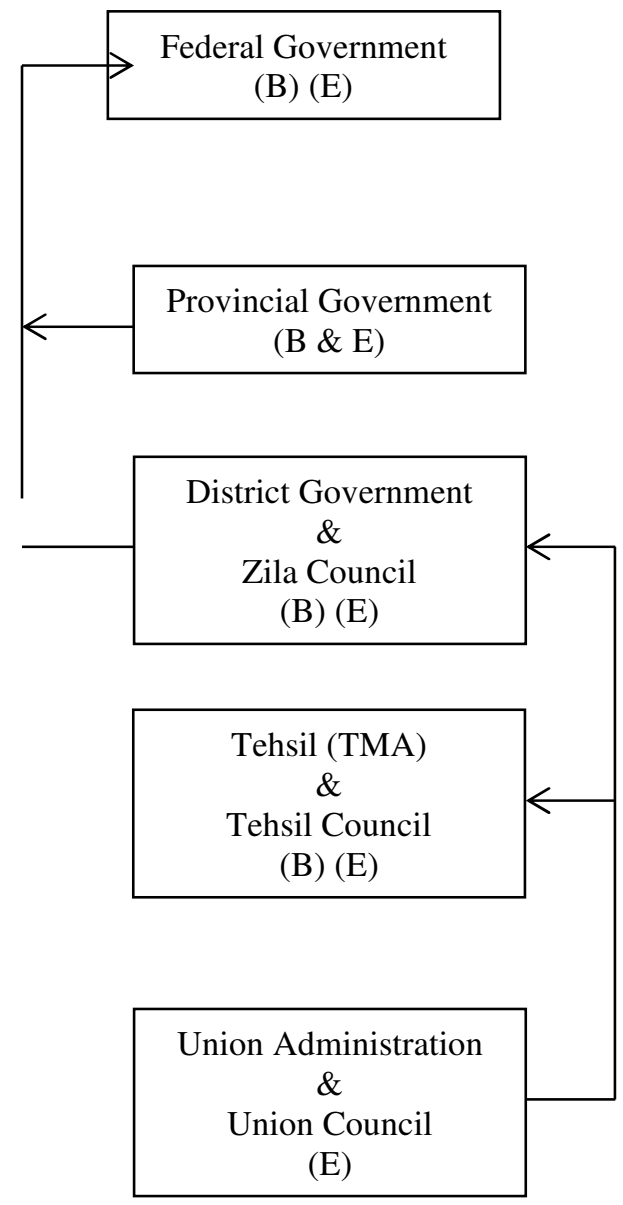

Source: Researcher's own illustration. Note: TMA = Tehsil Municipal Administration (B) stands for bureaucracy, while (E) stands for Elected.

The success of participatory and devolution reforms can be judged from the fact that in a study of the five most fragile countries, The researchers ${ }^{39}$ found out that among all, Pakistan offers the detailed processes of participatory reforms and decentralization. In addition, it has also achieved the objectives partially. After the general election of 2008, DOPP was halted. From 2009 until 2013 provinces experimented with different forms of these laws according to prevailing political expediency without any elected local government.

\subsection{Local Governments Acts of 2013}

In accordance with the 18th Amendment to the Constitution, the provincial assembly of Baluchistan passed the LG Act in 2010, whereas the provincial assemblies of Punjab, Sindh and Khyber Pakhtunkhwa passed their LG Acts in 2013. The LG Acts for each province, in

\footnotetext{
${ }^{39}$ Rafique, Zain., Khoo, Suet Leng, \& Idrees, Muhammad Waqas: “Civic engagement among the youth: empirical evidence from Kashmir, Pakistan”, Humanomics, Vol.32, no 3 (2016), pp. 376-388.
} 
their current form, provide limited autonomy to the local councils in terms of fiscal management and control over service delivery, revenue, tax and police departments. Currently, after the local government elections in all the provinces, provincial governments are struggling to ensure that newly elected local councils have sufficient resources and authority to address service delivery and development challenges in local communities. Under every provincial local government law, each council is intended to take proactive role in promoting citizen involvement, empowerment of citizens, identifying priorities and problems, organizing local microprograms, promoting civic education and gender equality, and organizing youth and recreational activities. (See a snapshot of all the local government history in Table 4 below)

Table 4. Local Government History

\begin{tabular}{|c|c|c|c|c|}
\hline \multicolumn{5}{|c|}{ Local government systems under military rule } \\
\hline Period & No. of years & $\begin{array}{l}\text { Military } \\
\text { Leader }\end{array}$ & $\begin{array}{l}\text { Name of } \\
\text { System }\end{array}$ & Distinguishing feature/s \\
\hline $1958-1969$ & 11 & $\begin{array}{l}\text { General } \\
\text { Ayub Khan }\end{array}$ & $\begin{array}{l}\text { Basic } \\
\text { Democracy }\end{array}$ & $\begin{array}{l}\text { National law; local } \\
\text { governments comprised } \\
\text { both elected and appointed } \\
\text { members, and served as an } \\
\text { electoral college for the } \\
\text { election of the national } \\
\text { President. }\end{array}$ \\
\hline $1979-1988$ & 9 & $\begin{array}{l}\text { General } \\
\text { Zia-ul-Haq }\end{array}$ & $\begin{array}{l}\text { No specific } \\
\text { name }\end{array}$ & $\begin{array}{l}\text { Elected local governments } \\
\text { under provincial laws; no } \\
\text { appointed members; 3-4 } \\
\text { successful terms completed } \\
\text { under this system. }\end{array}$ \\
\hline $1999-2008$ & 9 & $\begin{array}{l}\text { General } \\
\text { Pervez } \\
\text { Musharraf }\end{array}$ & $\begin{array}{l}\text { Devolution } \\
\text { of Power } \\
\text { Plan }\end{array}$ & $\begin{array}{l}\text { Based on the principle of } \\
\text { subsidiarity; radical } \\
\text { departure from all previous } \\
\text { systems; devolution } \\
\text { accompanied by taxation, } \\
\text { civil service, electoral and } \\
\text { police reforms. }\end{array}$ \\
\hline
\end{tabular}

\begin{tabular}{|c|c|c|}
\hline \multicolumn{3}{|c|}{ Local government under 'political' governments } \\
\hline Period & Political Situation & Remarks \\
\hline $1947-1958$ & $\begin{array}{l}\text { No constitution, no } \\
\text { elected government in } \\
\text { the country }\end{array}$ & $\begin{array}{l}\text { Urban Councils and District Boards in urban and rural } \\
\text { areas respectively continued according to laws left by the } \\
\text { British Government. }\end{array}$ \\
\hline $1971-1976$ & $\begin{array}{l}\text { First elected national/ } \\
\text { provincial } \\
\text { governments }\end{array}$ & $\begin{array}{l}\text { Despite promulgation of a local government law, no } \\
\text { elections held throughout this period and local councils } \\
\text { were managed through official administrators. }\end{array}$ \\
\hline $1988-1999$ & $\begin{array}{l}\text { Several elected } \\
\text { national governments } \\
\text { held power }\end{array}$ & $\begin{array}{l}\text { All elected local governments dismissed. Local } \\
\text { government elections never held though announced and } \\
\text { scheduled several times; elections held in certain } \\
\text { provinces in 1998, but elected representatives never } \\
\text { assumed office. }\end{array}$ \\
\hline $2009-2013$ & $\begin{array}{l}\text { Elected } \\
\text { national/provincial } \\
\text { governments }\end{array}$ & $\begin{array}{l}\text { All elected local governments dismissed. Local } \\
\text { government elections never held though announced and } \\
\text { scheduled }\end{array}$ \\
\hline 2013-tilldate & $\begin{array}{l}\text { Elected } \\
\text { national/provincial } \\
\text { governments }\end{array}$ & $\begin{array}{l}\text { Local government elections held in all the provinces. } \\
\text { Powers are being allocated. }\end{array}$ \\
\hline
\end{tabular}

Source: Authors own elaboration, 2020 


\section{Conclusion}

From the above findings and discussions, it can be concluded that in Pakistan, during the military regimes, local governance systems and participatory reforms were established to legitimize the government. Nevertheless, it promotes citizen participation and empowerment. On the contrary, each political government undermined the citizen participation and local governance and participatory reforms.

Moreover, it was concluded that during the democratic government, conflicts between local governments and provincial governments really undermined decentralization reforms. Currently, with an elected provincial and national government in place, conflicts are arising between the province and local governments. While the local governments have little revenue raising abilities and have effectively limited ability to decide their expenditures given that the majority expenditure is in the forms of fixed "establishment costs", the delivery of most public services has now come under their purview. While these local governments' future is still uncertain given their time-bound constitutional protection, their limited financial support and conflict with the provincial governments, what is clear is that if they remain, it is likely to see an impact on the delivery of these public services.

Nevertheless, citizen participation has been linked to successful institution building, accountable local government and stable state-society relations. As discussed earlier, the constitution of Pakistan states that local government institutions have the responsibility to make sure that all citizens are provided with services to satisfy their basic needs, in adherence to the vision of a developmental local government. Moreover, local government agencies are expected to involve citizens in service delivery mechanism. In Pakistan, where most of the population is not aware of their rights, citizen participation has potential to bring the change. An accountable, transparent and participation friendly local governance system can only be achieved through empowerment and participation of citizens.

Finally, this study has concluded that the current system of citizen participation is quite weak in the present local governance system. The current system of citizen participation and local governance, due to abovementioned findings, is not workable in Pakistan. Bottom up and participatory governance approaches are totally being ignored by health and sanitation sectors of Gujranwala. All the three prominent components of local governance system, functional, financial and structural are not functioning as per the defined decentralized acts and rules. For example, a local government institution, department or council is not structurally fit because federal or provincial law makers/ parliamentarians with the help of government officials are the main decision makers. Likewise, government institutions are not strong functionally as there is no mechanism of monitoring and evaluating the service delivery, project planning and implementation, involvement of citizens and other stakeholders. It was also found that rules regarding citizen participation and other participatory mechanisms can easily be manipulated even if they existed. Similarly, local government institutions have very limited financial autonomy. Mostly, they are dependent on provincial government for their expenditures. Thus, the financial component is also meager. Precisely, the researcher is of the view that visible government structure in Pakistan, may it be two tiers, three tiers, did not actually reach the grassroot level and thus also undermining citizen participation, bottom up approaches and participatory governance. Thus, under these grave circumstances, the researcher is of the view that a proper robust legal framework, acceptable to all stakeholders is needed. Laws, acts and rules regarding local governance and participatory governance needed to be changed. But there is a need of political will to do these changes as it is not easy, reason being the socio and cultural legacies of Pakistani society. In addition, without bureaucratic and political will, it not be possible to overcome these legal issues. 


\section{Bibliography}

Abers, Rebecca: "From clientelism to cooperation: local government, participatory policy, and civic organizing in Porto Alegre, Brazil”, Vol.26. no 4 (December, 2001), pp. 511-537.

Abraham, Kow Kwegya Amissah (2019): "The role and activities of policy institutes for participatory governance in Ghana." In Public Policy Research in the Global South, Cham, Springer, pp. 151-170.

Aguilera, Ruth and Cuervo-Cazurra, Alvaro: "Codes of good governance worldwide: what is the trigger?", Organization studies, Vol. 25, no 3 (2004), pp. 415-443.

Alam, Munnawar and Wajidi, Muhammad Abuzar: "Pakistan's Devolution of Power Plan 2001: A brief dawn for local democracy?", Commonwealth Journal of Local Governance, Vol. 12, $\mathrm{n}^{\circ}$ 1 (2012), pp.20-34.

Azmat, Fara, Alam, Quamrul and Coghill, Ken: "Integrated governance: A pre-requisite for sustainable market-oriented development in Bangladesh". International Journal of Public Administration, Vol. 32, no 10 (2009), pp. 829-851.

Bhave, Aditya. and Kingston, Christopher: "Military Coups and the consequences of durable De Facto Power: The case of Pakistan", Economics of Governance, Vol. 11, nº 1 (2010), pp. 51-76.

Cheema, Ali, Khwaja, Asim Ijaz and Qadir, Adnan: "Local government reforms in Pakistan: context, content and causes", Decentralization and local governance in developing countries: A comparative perspective, $\mathrm{n}^{\circ} 2$ (2006), pp. 257-284.

Cheema, Ghulam Shabbir: "Devolution with accountability: learning from good practices", in Cheema Ghulam Shabbir, Rondinelli Dennis A. (eds) (2007): Decentralizing Governance: Emerging Concepts and Practices, Washington DC, Brookings Institution Press, pp. 216-301.

Gauhar, A. (1996): Ayub Khan: Pakistan's First Military Ruler, New York, Oxford University Press.

Hasnain, Zahid: "Devolution, Accountability, and Service Delivery in Pakistan", The Pakistan Development Review, Vol. 49, no 2 (Summer 2010), pp.129-152.

Jabeen, Nasira and Iqbal, Muhammad Zafar: "Gender and local governance in Pakistan: Promoting participation through capacity building", South Asian Studies, Vol.25, nº 2 (2010), pp. 255-277.

Jalal, A. (1995): Democracy and Authoritarianism In South Asia: A Comparative and Historical Perspective, London, Cambridge University Press.

Khan, Shadi. (2006): Local Government and Participatory Rural Development. The Case Study of District Government in North Western Pakistan, DI Khan, Gomal University Press.

Lowndes, Vivien, Pratchett, Lawrence and Stoker, Gerry: "Trends in Public Participation: Part 1-Local Government Perspectives", Public Administration, Vol.79, no 1 (2001), pp. 205-222.

Mansuri, Ghazala. and Rao, Vijayendra: "Community-Based and-Driven Development: A Critical Review". The World Bank Research Observer, Vol.19, n 1 (2004), pp. 1-39.

Munir, Mughal. and Ahmad, Bashir. (1996): Constitution of the Islamic Republic of Pakistan: Being a Commentary on the Constitution of Pakistan, 1973, Lahore, PLD Publishers.

Musarrat, Razia, and Azhar, Sultan: "Decentralization Reforms in Pakistan During Ayub and Zia Era", Journal of Public Administration and Governance, Vol. 2, nº 1 (2012), pp.123-133. 
Myerson, Roger: "Constitutional structures for a strong democracy: considerations on the government of Pakistan", World Development, Vol. 53, no 2 (January 2004), pp. 46-54

Nurmandi, Achmad, and Purnomo, Eko Priyo: "Making the strategic plan work in local government: a case study of strategic plan implementation in Yogyakarta Special Province (YSP)", International Review of Public Administration, Vol. 16, $\mathrm{n}^{\circ} 2$ (2011): pp.143-164

Rafique, Zain and Khoo, Suet Leng: "Role of community-based organizations (CBOs) in promoting citizen participation: A survey study of local government institutions of Punjab, Pakistan", International Journal of Sociology and Social Policy, Vol.38, nº.3/4 (2018), pp. 242258.

Rafique, Zain., Khoo, Suet Leng, \& Idrees, Muhammad Waqas: "Civic engagement among the youth: empirical evidence from Kashmir, Pakistan”, Humanomics, Vol.32, no 3 (2016), pp. 376-388.

Rhodes, Raw: "The new governance: governing without government", Political studies, Vol.44, $\mathrm{n}^{\mathrm{o}} 4$ (1996), pp. 652-667.

Ritter, Michael, and Solt, Frederick: "Economic Inequality and Campaign Participation", Social Science Quarterly, Vol.100, nº 3 (2019), pp. 678-688.

Siddiqui, K. (1992): Local government in South Asia: a comparative study, Dhaka, University Press.

Sirker, Karen and Cosic, Sladjana. (2007): Empowering the Marginalized: Case Studies of Social Accountability Initiatives in Asia, Washington, D.C., The World Bank.

Stoker, Gerry. (1988): The politics of local government, London, Springer.

Tinker, Hugh. (1954): The Foundations of the Local Self-government in India, Pakistan and Burma, London, Athlone Press.

Wilder, Andrew. (1999): The Pakistani Voter: Electoral Politics and Voting Behaviour in the Punjab, London, Oxford University Press.

Zaidi, Syed Akbar: "Urban Local Government in Pakistan: Expecting Too Much from Too Little?", Economic and Political Weekly, Vol. 31, nº 44 (November 1996), pp. 2948-2953 